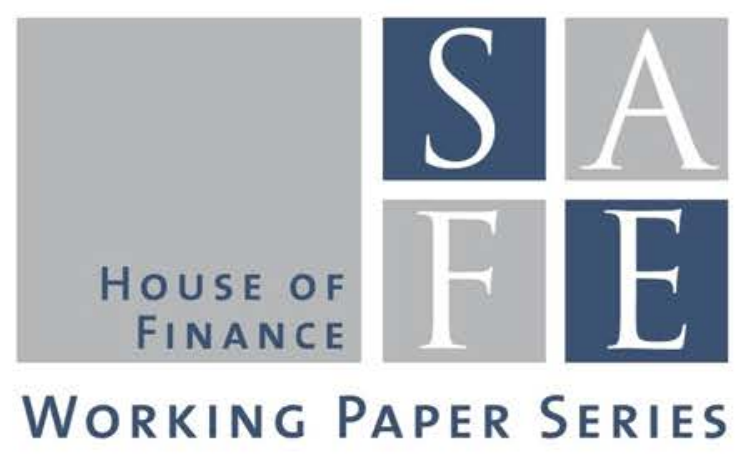

Yangming Bao - Martin R. Goetz

\title{
Local Peer Effects and Corporate Investment
}

SAFE Working Paper No. 220

SAFE I Sustainable Architecture for Finance in Europe A cooperation of the Center for Financial Studies and Goethe University Frankfurt 


\title{
Local Peer Effects and Corporate Investment*
}

\author{
Yangming Bao and Martin R. Goetz ${ }^{\dagger}$
}

July 7, 2018

\begin{abstract}
We examine how a firms' investment behavior affects the investment of a neighboring firm. Economic theory yields ambiguous predictions regarding the direction of firm peer effects and consistent with earlier work, we find that firms display similar investment behavior within an area using OLS analysis. Exploiting time-variation in the rise of U.S. states' corporate income taxes and utilizing heterogeneity in firms' exposure to increases in corporate income tax rates, we identify the causal impact of local firms' investments. Using this as an instrumental variable in a 2SLS estimation, we find that an increases in local firms' investment reduces the investment of a local peer firm. This effect is more pronounced if local competition among firms is stronger and supports theories that firm investments are strategic substitutes due to competition.
\end{abstract}

Keywords: Investments, Peer Effects, Agglomeration, Corporate Income Tax JEL Classification: G31, G38

\footnotetext{
${ }^{*}$ We are very thankful to Sonny Biswas, Casey Dougal, Laurent Fresard, Florian Heider, Alexander Hillert, Jan Krahnen, Thomas Mosk, Klaus Schaeck and seminar participants at Goethe University, the University of Bristol and the University of Exeter. Financial support from the Center of Excellence SAFE, funded by the State of Hessen initiative for research LOEWE is gratefully acknowledged.

${ }^{\dagger}$ SAFE and Goethe University Frankfurt, Theodor-W.-Adorno-Platz 3, 60323 Frankfurt am Main, Germany, Corresponding author: goetz@safe.uni-frankfurt.de
} 


\section{Introduction}

Evidence from social sciences indicates that our behavior is strongly affected by the behavior of other people around us. Peer effects, i.e. the impact of a group's behavior on individual behavior, are found to be important for productivity in the workplace, the accumulation of human capital, economic development or household financing decisions $\mathrm{H}^{1}$ Examining interactions among firms, empirical work finds that a firm's behavior is also affected by the behavior of its peer firms. For instance, firm peer effects help explain firms' mergers and acquisitions activity (Shue, 2013; Ahern and Harford, 2014; Fracassi, 2017) or their finance and investment decisions (Leary and Roberts, 2014; Dougal et al., 2015; Fracassi, 2017; Bustamante and Fresard, 2017).

In this paper, we focus on firms' investment decisions and examine how a corporation's investment behavior is affected by the investment of its neighbors. To identify the causal impact of firms' investment on their neighboring firms, we use an instrumental variable estimation technique based on the staggered, state-specific increase of corporate income tax rates in the United States.

Economic theory provides mixed predictions regarding the co-movement of firm investment decisions at the local level. On the one hand, the investment pattern of firms may be positively correlated as firms herd or mimic the investment behavior of their peers Scharfstein and Stein, 1990; Bikhchandani et al., 1992; Welch, 2000). A peer's stock price further contains important information, and managers can infer that information and follow in their investment behavior if they believe peers have superior information (Foucault and Fresard,

\footnotetext{
${ }^{1}$ Empirical evidence on the existence of peer effects is provided in Ichino and Maggi (2000); Mas and Moretti (2009); Hoxby (2000); Sacerdote (2001); Glaeser et al. (1996); Bayer et al. (2009); Duflo and Saez (2003); Hong et al. (2004) among others.
} 
2014). In addition to learning, localized networking among neighbors facilitate the deliberate information exchanges in cities (Arzaghi and Henderson, 2008). On the other hand, local firms compete for local resources. This renders their investment behavior to be negatively correlated. If local firms display similar demand for input factors, competition at the city level may imply that firms' investment decisions are strategic substitutes: a higher investment activity (and thus greater demand for inputs) by one firm reduces the (local) supply and forces peer firms to reduce their investment (Dixit, 1980).

Identifying the causal link running from a firm's investment to the investment of its neighbors is empirically challenging. A typical approach when estimating the presence of peer effects in corporate investments is to regress a variable of interest on the group mean of itself $^{2}$ (see e.g. Dougal et al. (2015); Leary and Roberts (2014)). OLS regressions using this empirical specification, however, do not allow the causal identification of peer effects and it is not possible to infer whether the average investment level causally affects firm investment or whether firm investments (and thus average investment) are driven by latent factors. This "reflection problem" (Manski, 1993) arises when a researcher aims at estimating whether the actions or characteristics of a group have an impact on the action of the individuals that comprise the group. The inclusion of fixed effects in panel regression models to account for unobservable latent factors does not address this problem as it introduces a negative correlation by construction between the investment of firms and the group mean of investment (Angrist, 2014).

We follow Dougal et al. (2015) and start by examining the correlation between U.S. firm investment and the average investment of their local neighbors, defined as firms headquar-

\footnotetext{
${ }^{2}$ The value of the unit under study is excluded from the computation of the group mean.
} 
tered in the same Economic Area (EA). Since firms in the same EA are subject to the same local environment, we consider firms within this area to be peers. Our OLS results confirm earlier findings of a positive relationship between firm investment and local peer firm investments in the same geographic area (Dougal et al., 2015). Due to the reflection problem, however, these results do not allow a causal interpretation 3

To identify the causal impact of local firm's investment, we employ a 2SLS estimation technique using changes in the state corporate income tax rates as an excluded instrumental variable. In particular, we build our identification strategy on two parts: first, we exploit variations in the exogenous rise in U.S. states' corporate income tax rates (Heider and Ljungqvist, 2015) to estimate the exogenous component of firm investment. In line with work showing that taxes are an important factor for firm investment Hall and Jorgenson, 1967; Summers, 1981; Zwick and Mahon, 2017), we find that corporate tax rises reduce firm investment. Second, we exploit heterogeneity in the headquarter locations of firms and use the fact that not all firms in the same EA are subject to the state-specific tax rise as they are located in the same EA, but headquartered in a different state. This allows us to recover the exogenous component of firm investment and hence pin down the causal link of investment on neighboring firms' investments.

Focusing on firms in the same area, but located in different states and using the exogenous rise in states' corporate income tax rates as an instrumental variable, we find that firms' investment exerts a negative effect on the investment behavior of a neighboring firm. Thus in contrast to our OLS findings, when firms increase their average investment, a neighboring

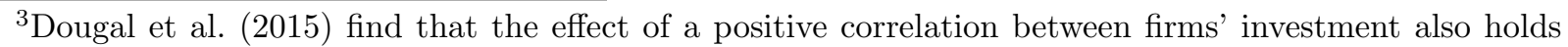
when restricting attention to firms in different industries. Their analysis presents evidence of a statistically robust and strong positive net effect of urban agglomeration. However, their approach does, for instance, not account for an endogenous selection of firms.
} 
firm responds by decreasing its investment. This finding also holds if we focus on firms in smaller areas, i.e. firms in metropolitan statistical areas.

Our empirical strategy exploits geographical variation within an EA to identify the causal link of peer effects and hence our identification assumption rests on the idea that a state's decision to raise taxes is exogenous to firm investment in the home and neighboring state(s). This assumption seems to be valid for two reasons. First, Heider and Ljungqvist (2015) find that "states feel freer to raise taxes when their neighbors levy higher taxes still" (p.692) and thus reduce tax competition. $4^{4}$ Second, we replicate the findings of Heider and Ljungqvist (2015) and examine whether the level or growth of investment at a state and its neighbors explains the decision to increase corporate taxes. We do not find evidence that a state's decision to increase corporate income taxes is significantly associated with investments.

In addition to the 2SLS analysis, we perform a reduced form analysis examining how firm investment changes when neighboring states increase corporate income tax rates. Moreover, we examine if the effect of a neighboring state's tax rise differs depending on a firm's proximity to that state. In line with our 2SLS findings, we find robust evidence that firms increase investment when neighboring states raise their corporate income tax rates. Furthermore, we find evidence for a spatial decay of this effect, as the effect is stronger for firms located in counties that are closer to the neighboring state. The increase in neighboring states' corporate income tax rates reduces neighboring firms' investment, and thus our reduced form finding is consistent with our 2SLS analysis.

Local peer firms may exert a negative impact on other firms' investments since they

\footnotetext{
${ }^{4}$ In particular, our identification assumption would be problematic if, say, state A lowers taxes in order to stimulate investment, and neighboring state B responds to A's tax cut by increasing taxes. This pattern is not present.
} 
compete for limited supply of input factors, rendering firms' investment decisions to be strategic substitutes (Dixit, 1980). Thus, this negative effect should be stronger if more peer firms are present in a certain area. To examine this, we refine our earlier definition of local peers and consider a firm's local peers to comprise of firms involved in the same industry (and area). Further, we use data on the degree of product market competition and compute local peer firms' investment using information on local product market competitors (Hoberg and Phillips, 2016). We find that the negative effect of firms' investment behavior on neighboring firms is stronger when more peers are present in an area. This supports the idea that competition for local input factors shapes firms' investment behavior.

Our findings contribute to the understanding of local firms' investment behavior. Dougal et al. (2015) find that firms in the same EA exhibit a similar investment pattern. They argue that this co-movement of investment arises from endogenous interactions within a city, such as technology spillovers between neighboring firms, or knowledge spread among workers. They further rule out endogenous local area shocks as they find that a firm's investment is also positively associated with total industry investment of firms, that belong to industries considered to be important for the local market, but are located outside the home area. While this rules out that local area shocks are driving the results, it it still possible that their findings are affected by an omitted variable bias $5^{5}$ Using the exogenous increase of state corporate income tax rates and exploiting heterogeneity in firm exposure to this shock, we can recover the exogenous component of firm investment and thus identify the causal

\footnotetext{
${ }^{5}$ For instance, firms of industry $A$ may decide to locate in certain areas if they are for instance suppliers of input factors for firms belonging to industry $B$, and industry $B$ is an important industry in that area. If investment of industry $B$ at the national level is driven by the investment of $B$ in that area, then firm $A$ 's investment behavior is not necessarily the result of spillovers among industries but is driven by $A$ 's role as a supplier of inputs for $B$.
} 
effect of local investment on other (local) firms' investment decision. Using this shock in a 2SLS estimation technique, we find that firm investment has a negative effect on neighboring firm's investment behavior. Thus, while peer effects among firms due to learning, mimicking or information exchange in vibrant urban areas may contribute to a net positive correlation of firm investment behavior, our findings suggest that the exogenous component of peer firm investments exerts a negative impact on other firm investments. Our work is also related to recent studies exploring peer effects in corporate behavior (Leary and Roberts, 2014; Foucault and Fresard, 2014; Kaustia and Rantala, 2015; Doidge and Dyck, 2015).

The closest paper to ours is the recent work by Bustamante and Fresard (2017), who also uses an instrumental variable strategy to identify the causal link of non-local peer effects. Contrary to our findings, Bustamante and Fresard (2017) finds a positive impact of peers on other firms' investment. Our analysis differs from their's in one important dimension: we focus on the effect of local peer firms while they focus on the effects of non-local peers. Competition for (local) input factors may be more important for shaping local peer effects and thus outweigh positive spillover effects due to learning or mimicking. Competition for local resources may be less severe for non-local peers and hence the positive spillover effects may prevail as found by Bustamante and Fresard (2017). Thus, we believe our results are complementary to their findings.

This paper is organized as follows: section 2 describes the data and empirical strategy. Section 3 presents the OLS estimations of local firm effects. Section 4 discusses our instrumental variable strategy, the 2SLS results as well as the reduced form analysis. Section 5 examines whether the local effect differs depending on the degree of local competition. Section 6 concludes. 


\section{Data and sample}

\subsection{Data source and variable construction}

We follow Heider and Ljungqvist (2015) and focus on publicly listed firms in the United States available in the CRSP/COMPUSTAT Merged database in the fiscal years 1989 to 2011. Similar to Heider and Ljungqvist (2015), we remove (a) companies not traded on the NYSE, Amex, or Nasdaq, (b) financial (SIC code 6), (c) utilities (SIC code 49), (d) public sector (SIC code 9) and (e) non-U.S. firms as well as (f) firms with a CRSP share code greater than 11. Information on state corporate income tax changes for the period 1989 to 2011 are provided by Heider and Ljungqvist (2015). Data on macroeconomic variables, i.e. a state's growth of GSP, unemployment rate, population and employment growth and union penetration is collected and constructed following Heider and Ljungqvist (2015).

Following Dougal et al. (2015), we examine the similarity of investment behavior among firms located in the same Economic Area (EA). EAs are defined by the Bureau of Economic Analysis (BEA) as relevant regional markets surrounding metropolitan areas, encompassing several counties and sometimes even spanning across state lines. EAs are considered to share social coherence and comprise a common regional market for labor, products and information.Using information on EAs' geographic boundaries of 2004 from the BEA, we map a firm into a specific EA based on that firm's headquarters zip codes.$^{6}$ In additional robustness tests, we examine the investment similarity among firms in the same metropolitan statistical areas (MSA).

\footnotetext{
${ }^{6}$ U.S. postal codes may span more than one county. In this case, we consider the firm to be headquartered in the county with the largest area share within a zip code.
} 
We measure firm $i$ 's investment during year $t$ by scaling its capital expenditure (compustat item capx) by the firm's net gross book value of fixed assets (compustat item ppent) in the previous year (Bustamante and Fresard, 2017):

$$
I_{i, t}=\frac{\operatorname{capx}_{i, t}}{\text { ppent }_{i, t-1}}
$$

Firm-level controls include Tobin's Q, cash flow, size, leverage, and ROA. Tobin's Q and cash flow are constructed based on Peters and Taylor (2017) 7 . In our regression models we control for macroeconomic factors at the state level, including growth of GSP, unemployment rate, growth of population, and state union penetration. Furthermore, we also include a measure of tax competition between neighboring states following Heider and Ljungqvist (2015), defined as the difference between a states corporate income tax rate and the highest corporate income tax rate levied by any of the neighboring states. Variable definitions are listed in Appendix A.

In our main specification, we use a first-difference estimator to account for firm unobservable characteristics. Thus we take first differences across all variables. To account for outliers, we winsorize all variables at the 0.5 percent level in each tail.

\footnotetext{
7 Peters and Taylor (2017) document that intangible capital plays an important role when studying firm investment and provide updated measures on capital and cash flow.
} 


\subsection{Empirical specification and identification}

\subsubsection{Empirical benchmark model}

We focus on firms in the same EA and consider a firm's peers to comprise of all other

local peer firms. The average investment of firm $i$ 's local peers $\left(\bar{I}_{-i, t}\right)$ at the EA-year level is computed following Dougal et al. (2015). Using a fixed effects panel regression, Dougal et al. (2015) find that a firm's investment is positively related to its local peers. We follow their approach and start with the following fixed effects OLS regression:

$$
\mathrm{I}_{i, t}=\alpha_{i}+\alpha_{t}+\alpha_{e}+\beta \bar{I}_{-i, t}+X_{i, t}^{\prime} \rho+\epsilon_{i, t},
$$

where $I_{i, t}$ is firm $i$ 's investment rate in year $t, \alpha_{i} / \alpha_{t} / \alpha_{e}$ are firm/year/EA fixed effects. $X_{i, t}^{\prime}$ is a set of firm and macroeconomic control variables. Specifically, we follow (Dougal et al., 2015) and include contemporaneous values of cash flow and lagged $q$ to account for their influence on investment. In addition, we control for other firm characteristics, including lagged value of size, leverage, and ROA. To capture the effect of changes in the macroeconomic environment on firm investment, we include lagged state's growth of GSP, unemployment rate, growth of population, state union penetration, and tax competition.

To examine the robustness of this approach and utilize changes in U.S. states' corporate income taxes in our later 2SLS analysis, our benchmark model utilizes a first-difference panel estimator. This is similar to the empirical setup of Heider and Ljungqvist (2015) who use a first-difference estimator to utilize the fact that some states increase corporate income tax 
rates more than once over the sample period: 8

$$
\Delta \mathrm{I}_{i, t}=\left(\delta_{i}\right)+\delta_{t}+\delta_{e}+\beta \Delta \bar{I}_{-i, t}+\Delta X_{i, t}^{\prime} \rho+\varepsilon_{i, t},
$$

where $\Delta$ is the first difference operator at the firm level, $\delta_{i}, \delta_{t}, \delta_{e}$ are fixed effects to capture unobservable differences across firms $(i)$, years $(t)$ or EAs $(e)$.

\subsubsection{Identifying the causal effect of firm investment}

Regression model (3) does not allow the identification of a causal link running from local neighbors' investment on firm $i$ 's investment. For instance, latent factors at the EAlevel, such as manager sentiment or urban vibrancy may drive the investment of firm $i$ and its local peers jointly (Dougal et al., 2015). To estimate the exogenous component of firm $i$ 's investment, we therefore exploit changes in state's corporate income tax rate as an instrumental variable.

There is a large literature examining the elasticity of investment with respect to (corporate) tax rates (Summers, 1981; Fazzari et al., 1988; Djankov et al., 2010; Yagan, 2015; Zwick and Mahon, 2017). We build on this work and construct instrumental variables based on increases in U.S. state corporate income tax rates to explain firm $i$ 's investment. To this end, we first examine whether an increase in a state's corporate tax rate affects firm $i$ 's investment. We then employ a two-stage-least squares (2SLS) methodology using instrumental variables based on the time-varying changes in U.S. corporate income taxes to recover the exogenous component of local peers' investment.

\footnotetext{
${ }^{8}$ It is not possible to account for multiple tax changes using a state- and time-fixed effects regression model.
} 


\subsection{Sample characteristics}

Our final sample contains 9,810 firms headquartered in the 48 contiguous states and covers the years 1989 to 2011 . Table 1 reports the descriptive statics of the main variables used in our sample. On average, a firm's annual investment rate is about 36 percent of its fixed assets. Moreover, the average firm has a size of about 1.6 billion US $\$$ and the average annual ROA amounts to 2.5 percent. In our 2SLS identification strategy, we restrict attention to firms located in EAs that span across state lines. There are 37 (out of 179) EAs that span across state lines and about 46.2 percent of all firms in our sample are headquartered in one of those EAs. Considering firm characteristics, the subsample of these firms tends to be similar to the total sampleg

\section{Firm investment and local peers' investments: OLS}

\section{results}

We start our analysis by estimating regression model (2) to replicate the findings of Dougal et al. (2015). Standard errors are robust and clustered at the firm level. All regression models account for unobservable firm characteristics, either by employing firm fixed effects or by applying a first difference estimator.

\footnotetext{
${ }^{9}$ T-test indicate that there are no significant differences in size, leverage, Tobin's Q, cashflow and ROA between the total sample and the subsample.
} 


\subsection{Results}

Table 2 reports regression results, where the findings of benchmark regression model of Dougal et al. (2015) are reported in column (1): the estimated coefficient on $\bar{I}_{-i, t}$ is positive and significant at the 1 percent level, indicating that a firm's investment is positively related to its neighbors' investment. Consistent with earlier work, we find that greater cash flow and higher $q$ is associated with more investment.

[Insert Table 2: Firm Investment and Local Peer Investment]

In column (2), we add industry-year fixed effects to control for unobservable time-varying industry specific differences in investment and continue to find a positive relationship between firms' investment rates. In column (3), we employ a first difference estimator instead of firm fixed effects and confirm the positive correlation between firm $i$ 's investment and the investment of its local peers. The effect also holds when we add firm fixed effects in column (4).

Our results confirm the findings of Dougal et al. (2015), as they show a positive relationship between firms' investment rates within an EA. This positive correlation among firms' investment is robust to different estimation techniques as well as industry-specific time ef-

fects. Dougal et al. (2015) distinguish the investment between local firms in the same and different industry. In an interesting analysis to uncover the causal link of urban vibrancy, they find that the investment behavior of local firms is positively related to the investment of non-local firms, operating in an industry that is very important for the local area ("dominant 
industry") ${ }^{10}$ Their analysis accounts for exogenous area shocks by construction and their finding suggests that local firms learn from the investment behavior of non-local firms, also involved in the dominant (local) industry. This positive effect could, however, also be due to joint exposure to a latent factor by these two industry groups. For instance, firms involved in non-dominant industries in certain areas may be input suppliers for firms belonging to the dominant industry in that area. If the dominant industry investment in an area is, however, determining the industry investment behavior outside that area then the positive relationship between a local firm's investment and the investment of the dominant non-local industry is due to the customer-supplier relationship between firms. Thus, the non-dominant industry's investment is still driven by the investment of the local dominant industry, which may be affected by local unobservable time-varying factors 11

\footnotetext{
${ }^{10}$ Dougal et al. (2015) define for each EA a dominant industry if the market capitalization of that industry exceeds $15 \%$ of total local market capitalization. Using that approach, Dougal et al. (2015) identify four areas and sectors: Atlanta (Nondurables), Detroit (Durables), Houston (Energy) and San Francisco Bay Area (Business Equipment). In a second step, they then relate the investment of all local firms, not involved in the dominant industry sector, to the nationwide investment of all non-local firms, involved in the dominant sector.

${ }^{11}$ Consider for instance firms in the San Francisco Bay Area: the sector "Business Equipment" is the dominant industry in the SF Bay Area. If technological innovations increase aggregate demand for business equipment and firms in the "Service" sector usually trade heavily with local firms, belonging to the sector "Business Equipment", then this aggregate demand shock primarily drives the investment of local nondominant industries. Thus, while the similarity of investments across firms may be due to a local unobservable factor, i.e. urban vibrancy, it is not necessarily caused by the investment of other firms, but driven by a local unobservable factor.
} 


\section{The impact of local firms' investment}

\subsection{State corporate income tax rates and firm investment \\ 4.1.1. Preliminaries}

Neoclassical theories argue that a firm's investment behavior is driven by profit maximization. Firm investment is therefore completely determined by a firm's $q$, i.e. the ratio of firm value to its capital stock (Abel, 1983; Hayashi, 1982). The testable implication of this theory is, however, not confirmed in the data and empirical work finds that additional financial factors, such as debt and cash flow play a role when examining firm investment (Gilchrist and Himmelberg, 1995). While this was initially thought to reflect financing constraints, a large theoretical literature shows that cash flow is indeed an important factor for investment (Abel and Eberly, 1994, 2011).

Corporate taxes represent costs for firms and thus affect a firm's cash flow. Whether and how taxes affect firm investment is thus a fundamental question in economics Hall and Jorgenson, 1967; Summers, 1981), $1^{12}$ Overall, empirical work presents evidence for a first-order effect of taxes on firm investment. For instance, Zwick and Mahon (2017) finds that temporary tax incentives in the U.S. on equipment investments boosts firm investment. Similarly, Ohrn (2016) finds that state specific changes in the treatment of depreciation can explain a rise in firm investment. Examining the relationship between corporate tax rates and investment in a cross-country study, Djankov et al. (2010) finds that corporate tax rates have an adverse effect on aggregate investment and entrepreneurial activity. Meanwhile,

\footnotetext{
${ }^{12}$ Empirical work aims at uncovering the elasticities of firms' investment with respect to business taxation (see among others Goolsbee (1998); House and Shapiro (2008)).
} 
taxes are important for corporate finance decisions (Dammon and Senbet, 1988). Desai and Hines (2004) finds that multinational companies take differences in local tax rates into account when choosing their financing mix: firms tend to increase their leverage in areas with a higher tax rate, consistent with theories highlighting the benefits of a tax shield of debt. Similarly, Desai et al. (2016) finds that affiliates of multinational U.S. companies use trade credit to lend in low-tax jurisdictions, whereas affiliates in high-tax jurisdictions use trade credit to borrow. Exploiting changes in states' corporate income tax rates, Heider and Ljungqvist (2015) finds that increases in state tax rates increase a firm's debt, consistent with the existence of a debt tax shield. Asker et al. (2015) shows that private firms increase investment spending in response to tax cuts and reduce it in response to tax increases 13

\subsubsection{States' corporate income tax rates in the U.S.}

States in the U.S. usually tax corporate activities within their state borders by taxing profits or revenues. Moreover, firms that have a presence in more than one state ("multi-state firms") are subject to state corporate income tax in every state where they have a physical presence, and their taxable income in each state is determined using an apportionment formula. 14

Heider and Ljungqvist (2015) shows that states are quite active in rising and cutting corporate tax rates over the period 1989 - 2011. Their analysis indicates that economic and political conditions play an important role in U.S. states' changes of taxes. States that rise

\footnotetext{
13 Asker et al. (2015) finds little evidence of changes in public firms' investment behavior due to tax shocks. Different to their setting, we focus on changes in growth rates of investment and find a first-order effect of tax increases on firm investment.

${ }^{14}$ This apportionment is based on an average of the fractions of the firm's total payroll, sales, and property located in that state (Heider and Ljungqvist, 2015).
} 
corporate taxes, for instance, tend to have a Democratic governor and are more likely to have a state budget deficit in the previous year. Exploiting 121 changes in corporate tax rates over this period, Heider and Ljungqvist (2015) finds that an increase in U.S. states' corporate tax rates increases firm leverage, consistent with dynamic trade-off theories of capital structure 15

We first examine how changes in states' corporate income tax rates affect firm investment. Then we use the exogenous increases in states' corporate income tax rates as an instrumental variable in our regression model to identify the causal impact of peer firms on investment.

\subsection{Tax rises and firm investment}

\subsubsection{Determinants of tax rises}

The underlying assumption for our identification strategy is that a state's tax rise is exogenous to firm investment. Therefore, we assume that the change in corporate income tax rate in a state is unanticipated by firms headquartered in that state. Moreover, to identify the causal effect of local firms' investment on peer firms, a neighboring state's corporate tax rate change has to be exogenous to the investment of firms in another state.

Heider and Ljungqvist (2015) investigates determinants of corporate tax changes and the empirical evidence suggests that the decision to increase corporate income tax rates is driven primarily by idiosyncratic political factors at the state-level. Analyzing the spatial pattern of tax changes, Heider and Ljungqvist (2015) finds that states rise corporate tax

\footnotetext{
${ }^{15}$ Recent work finds that taxes not only affect firms' leverage, but also risk taking. In particular, Ljungqvist et al. (2017) finds that the average firm reduces risk in response to an increase of U.S. states' corporate tax rates. Focusing on real effects, Ljungqvist and Smolyansky (2014) compares contiguous counties of neighboring states and find that an increase in a state's corporate tax rate leads to a decrease in employment and a reduction in income.
} 
rates when their corporate tax rate is lower than those of their neighbors. We replicate their findings and examine further whether the investment level of firms within a state and/or the investment level of firms in a neighboring state is associated with the timing of a state's corporate income tax rise. Similar to Heider and Ljungqvist (2015), we estimate a state and time fixed effects regression of corporate tax rises on political and economic determinants, and the aggregate investment and growth at a state and its neighbors.

[Insert Table 3. Determinants of State Corporate Income Tax Rises]

Results from estimating this regression model are reported in Table 4 . Consistent with Heider and Ljungqvist (2015), we find that the degree of tax competition among neighboring states as well as the fiscal situation of the state is associated with the timing of corporate tax rises. We do not find evidence that local firms' investment or the investment of firms in a neighboring state affects the timing of corporate tax increases. Therefore, this analysis does not provide evidence that the timing of state corporate tax rates is associated with the level of firm investment in the state or firm investment in neighboring states.

\subsubsection{The effect of tax rises on firm investments}

Motivated by theories and evidence examining the importance of taxes on firm investment (Djankov et al., 2010; Zwick and Mahon, 2017; Ohrn, 2016), we now study how an increase in state corporate income tax rates affects firm investment in the U.S. ${ }^{16}$ We use state corporate income tax rates based on the location of firms and estimate a difference-in-differences model.

\footnotetext{
${ }^{16}$ We also analyzed whether a decrease in a state corporate income tax rate stimulates investments but were not able to find any significant relationship between firm investment and state corporate income tax reductions. Thus, we focus on increases in a state's corporate income tax rate.
} 
As mentioned earlier, multi-state firms are taxed in states where they operate. Detailed information on the location of a firm's subsidiaries across states are not available and hence we cannot account for the fact that some firms may be exposed less to a local corporate tax rise, since they are active in different states. Heider and Ljungqvist (2015) collect information on firms' geographical spread and account for potential differences in firms' exposure to a local tax change. Their findings are not sensitive to this and hence they conclude that focusing on a firm's home states tax changes appears to be an innocuous approximation. We follow their assessment and thus assume that firms only operate in their home state. Specifically, we follow Heider and Ljungqvist (2015) and estimate the following first-difference regression model: $\left[\begin{array}{l}17 \\ {[}\end{array}\right.$

$$
\Delta I_{i, t}=\beta T_{s, t}+\gamma \Delta X_{i, t}+\delta_{k, t}+\delta_{i}+\varepsilon_{i, t}
$$

where $I_{i, t}$ is firm $i$ 's investment rate at time $t ; T_{s, t}$ is a dummy variable taking on the value of one if state $s$ increases its corporate income tax in year $t$, and zero otherwise; $X_{i, t}$ is a set of (a) firm control variables and (b) macro control variables to account for changes in the macroeconomic environment due to the tax change; $\delta_{k, t}$ is a set of industry-specific time dummies and $\delta_{i}$ are firm fixed effects. We account for the effect of firms' $q$ and cash-flow by including these control variables in the analysis. Ljungqvist and Smolyansky (2014) finds that changes in corporate income tax rates also affect the economy, and we account for the effect of tax changes on the local economy. Specifically, we include the lagged values of GSP growth, unemployment rate, union penetration, tax competition, population growth and

\footnotetext{
${ }^{17}$ States can exhibit several changes in their corporate tax rate over the sample period. A first-difference estimator therefore allows us to exploit multiple tax changes in a state.
} 
employment growth of the firm's home state. The coefficient of interest is $\beta$ which estimates the impact of an increase in states' corporate income tax rate on firm investment.

[Insert Table 4: State Corporate Income Tax and Corporate Investment]

Regression results from estimating regression (4) are reported in Table 3 . The results show that a rise in state corporate income tax rates leads to a significant drop in investment, as indicated by the negative coefficient on the tax rise dummy. This effect is also robust to the inclusion of EA-year fixed effects, which capture time-varying changes in investment at the EA-level (column 2). Because some EAs extend across state lines, we can include EA-year fixed effects and examine whether the investment rate of firms in the same area and year differs due to the increase in state corporate tax rates. The coefficient in column 2 is identified by comparing the investment rate of firms in the same EA, where a group of firms is headquartered in a state that rises corporate tax rates, while other firms are located in a different state that does not change corporate tax rates. Even conditioning on unobservable time-varying differences in firm investment at the EA-level, we find that a tax rise reduces firms' investments. Moreover, our results show that the investment reducing effect of corporate tax rises remains if we include firm and macroeconomic control variables (column 3) to control for heterogeneity across firms and account for effects of the tax change on the local economy. Furthermore, we find that a tax rise significantly reduces firm investment if we add firm fixed effects to control for unobservable time-invariant heterogeneity across firms in column 4.

The rise in corporate income tax rates is a shock to firm investment. To examine whether 
(a) firms already adjust investment prior to the tax rise or (b) exhibit also a drop in investment after the year of the tax increase, we augment regression model (4) and add two further tax rise dummy variables: a pre-tax-rise/post-tax-rise dummy variable taking on the value of one in the year before/after the tax rise. Our regression results indicate that a tax rise is not associated with anticipatory effects as firms don't adjust their investment a year before the tax rise. Furthermore, we also don't find evidence for a permanent reduction in investment changes due to tax rises as the coefficient on the post-tax-rise dummy variable is not significantly different from zero (column 5). Finally in column 6, we capture unobservable changes in an industry's investment at the EA-level by including EA-industry-year fixed effects. Our results are robust and we continue to find that rises in corporate tax rates are followed by a contemporaneous reduction in firm investment, but do not display permanent reductions in investment growth.

\subsection{Identifying peer effects: Multi-state EAs and state corporate income tax shocks}

Our regression analysis indicates a robust first-order effect of a tax rise on firm investment. Armed with this insight, we develop three instrumental variables to identify the causal link of firm investment on neighboring firms' investment. For our identification strategy, we focus on EAs that span more than one state ("multi-state EAs") and estimate the exogenous component of local peers' investment based on the corporate tax rise shock. Thus, we exploit the fact that a rise in state corporate income tax rates (a) only affects firms that have a physical presence in that state and (b) does not directly affect local peers, i.e. firms 
located in the same EA, but headquartered in a neighboring state.

Overall, there are $37 \mathrm{EAs}$ that span more than one state and about 46 percent of all firms in our sample are located in a multi-state EA. To illustrate our identification strategy, consider the New York-Newark-Bridgeport EA, depicted in Figure 2.

[Insert Figure 2 about here]

The New York-Newark-Bridgeport EA spans four different states: NY, NJ, CT and PA. Firms in our sample are scattered across this EA, and our sample contains firms headquartered in any of the four states. In 2002, NJ experienced its largest increase in business taxes since 1945 in face of a budget deficit. This increase in corporate income tax represents a shock to the financing and investment of firms headquartered in NJ, but is exogenous to the investment behavior of firms headquartered in any of the other three states. Thus, we can identify the exogenous component of investment for NJ-firms due to the increase in corporate income tax rates. Since NJ-firms are part of the local peer group of this EA, but headquartered in a different state, we can estimate the exogenous component of local peer firm investment for these unaffected firms and hence identify the causal impact of local peer effects.

The underlying assumption for our identification strategy is that the tax rise in firm $j$ 's state only affects the investment of firm $i$ headquartered in a neighboring state due to changes in $j$ 's investment behavior. If the investment behavior of firm $i$ determines the decision of another state to increase its corporate income tax rate, then the orthogonality assumption of our IV estimation is not valid. As indicated by the results in Table 4, we do 
not find evidence that the level of local firm investment or the investment in neighboring states is associated with the timing of tax changes.

To further isolate the effect of a neighboring state's increase on corporate taxes, we exclude firms that were themselves subject to a tax increase in the same year. Thus, we only keep firm-years in multi-state EAs if their home state did not increase corporate income tax rates. The final sample for the 2SLS analysis consists of 4,669 firms.

\subsection{The causal impact of peers' investment behavior: 2SLS Results}

\subsubsection{First stage: Tax rise and peer firm investment}

The endogenous variable is the average investment rate of local peers for firm $i$, excluding

firm $i$. To estimate the exogenous component of peer firms' investment, we employ three instrumental variables based on the increase in U.S. states' corporate income tax rates. First, we use a dummy variable taking on the value of one if there is a tax rise in a state belonging to a multi-state EA but firm $i$ is not located in that state (=1 if tax rise in neighboring state). Second, we use insights from Table 3 and estimate the predicted average investment shocks on local peer firms due to the tax increase as follows: first we use regression model (4) and compute the state-specific effect of a tax rise on firm investment $\left(\hat{I}_{i, t}\right)$ by allowing the coefficient on the tax rise dummy to vary across states. The estimated coefficients capture heterogeneity in the effect of tax changes on firm investment across states. In comparison to the tax dummy this estimated state-specific tax shock provides a better assessment of the magnitude of the tax shock on firm investment. Similar to the main independent variable, we construct an instrumental variable by calculating the average predicted change in peers' 
investment rate $\Delta \overline{\hat{I}}_{-i, t}$ as the change in the average of $\hat{I}_{i, t}$ across all other firms in an EA (Predicted state-specific $\Delta \bar{I}_{-i, t}$ ). Third, we further allow the effect of the tax rise to vary by industry and state and estimate the state-industry-specific reduction in firm investment due to a tax rise. As before, we compute the average across all other firms in an EA to construct the instrumental variable Predicted state-industry-specific $\Delta \bar{I}_{-i, t}$. The last two instrumental variables allow us to capture heterogeneity in the effect of a tax rise on peer firm investment based on a regression model.

[Insert Table 5: The Causal Effect of Local Peer Investment]

Panel B of Table 5 reports first stage regression results using these excluded instrumental variables to explain peer firm investments. Consistent with our findings at the firm-level (Table 4), we find that an increase in corporate income tax rates reduces average firm investment, as indicated by the negative and statistically strong coefficient on the tax rise dummy (column 1). The coefficient on the predicted state-specific change (column 2) and state-industry specific change (column 3) on investment in the first stage, on the other hand, is positive, indicating that our predicted drop in peer firm investment due to a tax rise correlates positively with the observed drop in investment. Across all excluded instrumental variables, we find a statistically strong relationship between the excluded instruments and peer firm investment and the F-Tests regarding the significance of the excluded instruments are above 10 across all specifications. 


\subsubsection{Second stage results: the impact of peers on firm investment}

Panel A of Table 5 reports second stage regression results, analyzing the impact of firm investment on local neighbors' investment. Different to our OLS findings, we find that firm investment has a negative effect on a neighbor's investment in the 2SLS analysis, as indicated by the negative and statistically significant coefficient. Further, the effect is not sensitive to the employed instrumental variable, as we find a negative link running from firm investment on neighboring firms' investment across all instrumental variables. Focusing on the coefficient reported in column 1 of Table 5, we compute that a tax increase in a neighboring state reduces local firms' investment growth by 50 basis points. This exogenous reduction in firms' investment boosts a local neighbor's investment growth by about 2 percent.

Although our OLS results are consistent with the findings of Dougal et al. (2015), our 2SLS results show that local peers have a negative effect on firm investment. Hence, while agglomeration effects, such as "urban vibrancy" (Dougal et al., 2015) may contribute positively to the co-movement on firm investments, the causal individual effect of peer investment on firm investment is negative.

The identified negative local peer effect is also different to the positive peer effect found in Bustamante and Fresard (2017). They find that the investment behavior of firms has a positive impact on the investment behavior of non-local peers, defined as product market competitors, headquartered in another area. We differ from their analysis as we focus on the link among investment of firms located in the same area (Dougal et al., 2015). Bustamante and Fresard (2017) on the other hand, focus on non-local rival firms and thus assess the similarity of investment behavior among non-local product market competitors (Hoberg and 
Phillips, 2016), located in different areas. While the identification strategy of Bustamante

and Fresard (2017) allows the identification of a causal impact of non-local peer firms' investment, the different findings may be due to differences in focusing on local and non-local peers firms. Local peers, i.e. firms in the same EA, are more likely to compete for a limited supply of local input factors. This competition for local resources (Dixit, 1980$)$ may dominate a firm's investment decision and outweigh potentially positive effects due to learning or mimicking from other firms' investment (Leary and Roberts, 2014; Frésard and Valta, 2015).

\subsection{Robustness tests: Alternative area definition}

Our unit of geography is an EA and EAs are considered to represent relevant regional markets for labor, products and information. To examine whether local peer effects are present at a smaller region, we re-examine our analysis and focus on peer firm effects within the same MSAs. MSAs are geographic entities that contain a core urban area of 50,000 or more inhabitants and include adjacent counties with a high degree of social and economic integration with the urban core. Following our earlier approach, we restrict attention to MSAs that span more than one state and construct instrumental variables based on our earlier methodology 18 Table 6 presents the regression results for this analysis. Similar to our earlier results, we find that local firms' investment exerts a negative impact on firm investment at the MSA-level, indicating that our finding is not driven by the definition of geography.

\footnotetext{
${ }^{18}$ Since MSAs are smaller than EAs, our sample becomes smaller in this analysis. Overall our sample consists of about 2,000 firms in 15 distinct MSAs to identify the impact of peer firms' investment in this analysis.
} 


\subsection{Reduced form: tax rise in neighboring states and firm investment}

Our 2SLS findings suggest that a tax rise in a neighboring state boosts peer firms' investment as it reduces the investment of firms, that are subject to the tax rise. To examine this link further, we analyze the reduced form of this channel and estimate:

$$
\Delta I_{i, t}=\beta_{1} T_{s, t}+\beta_{2} T_{-s, t}+\gamma \Delta X_{i, t-1}+\delta_{k, t}+\delta_{i}+\varepsilon
$$

where $T_{s, t}$ is a dummy variable taking on the value of one whether firm $i$ 's home state $s$ raises the corporate income tax rate in year $t$, or zero otherwise; $T_{-s, t}$ is a dummy variable taking on the value of one whether a neighboring state of firm $i$ 's home state raises the corporate income tax rate in year $t$, or zero otherwise; $X_{i, t-1}$ is the set of firm and macroeconomic control variables and $\delta$ are a set of firm and industry-year fixed effects.

[Insert Table 7 Border States' Tax Rises on Investment (Reduced Form Analysis]

We estimate equation (5) using the full sample of firms and present the results in Table 7. Similar to the results on the impact of tax rises on firm investment, we find that firms reduce investment when their home state increases corporate income taxes. Interestingly, the coefficient on $T_{-s, t}$ is positive and significant at the 1 percent level, indicating that local firms increase investment when a neighboring state raises corporate tax rates. In column 2, we differentiate this effect further and examine whether the impact of a tax rise in a neighboring state differs depending on a firm's proximity to that state. In particular, we distinguish between firms located in a border county, i.e. a county adjacent to a state that 
raises corporate income tax rates and firms in counties that do not border another state.

Our results show that a tax rise in a neighboring state only boosts firm investment if that firm is located in a bordering county as indicated by the positive and statistically significant coefficient. While we continue to find a positive effect on firm investment for firms in nonbordering counties, this effect is not statistically significant. This finding is robust to the inclusion of EA fixed effects (column 3), firm fixed effects (column 4), EA-year fixed effects (column 5) and even EA-industry-year fixed effects (column 6). The statistically significant coefficient when adding EA-year fixed effects shows that even within the same area only firms located close to a neighboring state that raises corporate income tax rates increase their investment. Firms headquartered further away from that state do not significantly increase their investment when neighboring states raise taxes.

\section{Local firm effects and presence of peers}

Our findings show that firms exhibit a negative effect on neighboring firms' investment. In addition to our IV regression results, reduced form findings support this conclusion, as they are consistent with the idea that an increase in corporate income taxes reduces firm investment but boosts investments by local firms, that are not directly affected by the tax shock. Thus, our conclusion supports theories arguing that firm investments are strategic substitutes due to competition (Dixit, 1980).

To examine this competition channel further, we hypothesize that the negative effect of local firms' investment is stronger if more local competitors are present in an area. To examine whether local peer effects are indeed more negative when more competitors are 
present, we augment the benchmark regression model and estimate the differential effect of peer effects depending on the presence of local competitors:

$$
\Delta \mathrm{I}_{i, t}=\delta+\beta_{1} \Delta \bar{I}_{-i, t}+\beta_{2} \Delta \bar{I}_{-i, t} \cdot C_{i}+\Delta X_{i, t}^{\prime} \rho+\varepsilon_{i, t},
$$

where $C_{i}$ is an indicator variable taking on the value of one whether a firm faces more competition due to the presence of similar firms in an EA, or zero otherwise. Specifically, we define two variables that capture whether a firm faces more competition from its local firms: first, we consider a firm to face more competition in an EA if the asset share of all firms in an EA, involved in the same Fama-French 12 industry as firm $i$, is above the average median share across all EAs. Second, we use firm-specific information provided by Hoberg and Phillips (2016) regarding the presence of product market competitors and compute the asset share of all local product market competitors, i.e. the share of assets in an EA that belong to firms that are considered to be product market competitors to firm i. Based on the sample median asset share, we then consider firms in EAs where more local product market competitors are present to face higher local competition. Using the earlier introduced instrumental variables, we instrument the interaction of $\Delta \bar{I}_{-i, t} \cdot C_{i}$ with the interaction of the instrumental variable and $C_{i}$ to estimate the causal differential impact of peer firm investment $\left(\beta_{2}\right)$.

[Insert Table 8; Local Peer Effect and Competition]

Table 8 reports second stage regression results from estimating regression model (6). The 
coefficient on the interaction of peer investment and our competition variable is negative and statistically significant across all employed instrumental variables. This suggests that local peer effects are stronger if more competitors are present and thus is consistent with the idea that local firms' investments are strategic substitutes.

\section{Conclusion}

This paper empirically analyzes the effect of local firm investment on the investment of neighboring firms. Estimating the causal effect of local peers on firm investment is challenging due to reflection problem and common unobservable local factors. We address these challenges by employing a 2SLS estimation technique using instrumental variables based on exogenous changes in state corporate income tax and identifying the causal impact of local peer effects. Contrary to the OLS findings, our 2SLS regression results indicate that local peers have a negative effect on a firm's investment. The results are robust to additional fixed effects and not sensitive to the definitions of geographic unit. Furthermore, we examine whether firm peer effects differ if more local competitors, i.e. firms of the same industry group or rivals, are present. Our findings show that the negative effect of peers is stronger for industries where more competitors are present, which are consistent with theories arguing that local peer investments are strategic substitutes (Dixit, 1980). 


\section{References}

Abel, A. B. (1983). Optimal investment under uncertainty. American Economic Review $73(1), 228-233$.

Abel, A. B. and J. C. Eberly (1994). A unified model of investment under uncertainty. American Economic Review 84(5), 1369-1384.

Abel, A. B. and J. C. Eberly (2011). How Q and cash flow affect investment without frictions: An analytic explanation. Review of Economic Studies 78(4), 1179-1200.

Ahern, K. R. and J. Harford (2014). The importance of industry links in merger waves. Journal of Finance 69(2), 527-576.

Angrist, J. D. (2014). The perils of peer effects. Labour Economics 30, 98-108.

Arzaghi, M. and J. V. Henderson (2008). Networking off madison avenue. Review of Economic Studies 75(4), 1011-1038.

Asker, J., J. Farre-Mensa, and A. Ljungqvist (2015). Corporate investment and stock market listing: A puzzle? Review of Financial Studies 28(2), 342-390.

Bayer, P., R. Hjalmarsson, and D. Pozen (2009). Building criminal capital behind bars: Peer effects in juvenile corrections. Quarterly Journal of Economics 124(2), 1-34.

Bikhchandani, S., D. Hirshleifer, and I. Welch (1992). A theory of fads, fashion, custom, and cultural change as informational cascades. Journal of Political Economy 100(5), 992-1026.

Bustamante, M. C. and L. Fresard (2017). Does firm investment respond to peers investment? Working Paper. 
Dammon, R. M. and L. W. Senbet (1988). The effect of taxes and depreciation on corporate investment and financial leverage. Journal of Finance 43(2), 357-373.

Desai, Mihir AFoley, C. F. and J. R. Hines (2004). A multinational perspective on capital structure choice and internal capital markets. Journal of Finance 59(6), 2451-2487.

Desai, M. A., C. F. Foley, and J. R. Hines (2016). Trade credit and taxes. Review of Economics and Statistics 98(1), 132-139.

Dixit, A. (1980). The role of investment in entry-deterrence. Economic Journal 90(357), $95-106$.

Djankov, S., T. Ganser, C. McLiesh, R. Ramalho, and A. Shleifer (2010). The effect of corporate taxes on investment and entrepreneurship. American Economic Journal: Macroeconomics 2(3), 31-64.

Doidge, C. and A. Dyck (2015). Taxes and corporate policies: Evidence from a quasi natural experiment. Journal of Finance 70(1), 45-89.

Dougal, C., C. A. Parsons, and S. Titman (2015). Urban vibrancy and corporate growth. Journal of Finance 70(1), 163-210.

Duflo, E. and E. Saez (2003). The role of information and social interactions in retirement plan decisions: Evidence from a randomized experiment. Quarterly Journal of Economics 118(3), 815-842.

Fazzari, S. M., G. R. Hubbard, and B. C. Petersen (1988). Financing constraints and corporate investment. Brookings Papers on Economic Activity 1, 141-206. 
Foucault, T. and L. Fresard (2014). Learning from peers' stock prices and corporate investment. Journal of Financial Economics 111(3), 554-577.

Fracassi, C. (2017). Corporate finance policies and social networks. Management Science 63(8), 2420-2438.

Frésard, L. and P. Valta (2015). How does corporate investment respond to increased entry threat? Review of Corporate Finance Studies 5(1), 135.

Gilchrist, S. and C. P. Himmelberg (1995). Evidence on the role of cash flow for investment. Journal of Monetary Economics 36(3), 541-572.

Glaeser, E., B. Sacerdote, and J. Scheinkman (1996). Crime and social interactions. Quarterly Journal of Economics 111(2), 507-548.

Goolsbee, A. (1998). Investment tax incentives, prices, and the supply of capital goods. The Quarterly Journal of Economics 113(1), 121-148.

Hall, R. E. and D. W. Jorgenson (1967). Tax policy and investment behavior. American Economic Review 57(3), 391-414.

Hayashi, F. (1982). Tobin's marginal q and average q: A neoclassical interpretation. Econometrica 50(1), 213-224.

Heider, F. and A. Ljungqvist (2015). As certain as debt and taxes : Estimating the tax sensitivity of leverage from state tax changes. Journal of Financial Economics 118(3), $684-712$. 
Hoberg, G. and G. Phillips (2016). Text-based network industries and endogenous product differentiation. Journal of Political Economy 124(5).

Hong, H., J. D. Kubik, and J. C. Stein (2004). Social interaction and stock market participation. Journal of Finance 59(1), 137-163.

House, C. L. and M. D. Shapiro (2008). Temporary investment tax incentives: Theory with evidence from bonus depreciation. American Economic Review 98(3), 737-768.

Hoxby, C. M. (2000). Peer effects in the classroom: Learning from gender and race variation. NBER Working Paper No. 7867.

Ichino, A. and G. Maggi (2000). Work environment and individual background: Explaining regional shirking differentials in a large Italian firm. Quarterly Journal of Economics 115(3), 1057-1090.

Kaustia, M. and V. Rantala (2015). Social learning and corporate peer effects. Journal of Financial Economics 117(3), 653-669.

Leary, M. T. and M. R. Roberts (2014). Do peer firms affect corporate financial policy? Journal of Finance 69(1), 139-178.

Ljungqvist, A. and M. Smolyansky (2014). To cut or not to cut? On the impact of corporate taxes on employment and income. Working Paper.

Ljungqvist, A., L. Zhang, and L. Zuo (2017). Sharing risk with the government: How taxes affect corporate risk taking. Journal of Accounting Research 55(3), 669-707. 
Manski, C. F. (1993). Identification of social endogenous effects: The reflection problem. Review of Economics and Statistics 60(3), 531-542.

Mas, A. and E. Moretti (2009). Peers at work. American Economic Review 99(1), 112-145.

Ohrn, E. (2016). Investment and Employment Responses to State Adoption of Federal Accelerated Depreciation Policies. Working Paper.

Peters, R. H. and L. A. Taylor (2017). Intangible capital and the investment-q relation. Journal of Financial Economics 123(2), 251-272.

Sacerdote, B. (2001). Peer effects with random assignment: Results for Dartmouth roommates. Quarterly Journal of Economics 116(2), 681-704.

Scharfstein, D. S. and J. C. Stein (1990). Herd behavior and investment. American Economic Review $80(3)$, 465-479.

Shue, K. (2013). Executive networks and firm policies: Evidence from the random assignment of MBA peers. Review of Financial Studies 26(6), 1401-1442.

Summers, L. H. (1981). Taxation and corporate investment: A q-theory approach. Brookings Papers on Economic Activity (1), 67-140.

Welch, I. (2000). Herding among security analysts. Journal of Financial Economics 58(3), 369-396.

Yagan, D. (2015). Capital tax reform and the real economy: The effects of the 2003 dividend tax cut. American Economic Review 105(12), 3531-3563. 
Zwick, E. and J. Mahon (2017). Tax policy and heterogeneous investment behavior. American Economic Review 107(1), 217-248. 


\section{Fig. 1. A map of Economic Areas in the United States}

This figure plots the geographic boundaries of Economic Areas (EAs) in the United States as defined by the Bureau of Economic Analysis in 2004. The red shaded areas are the EAs that spread across state borders.

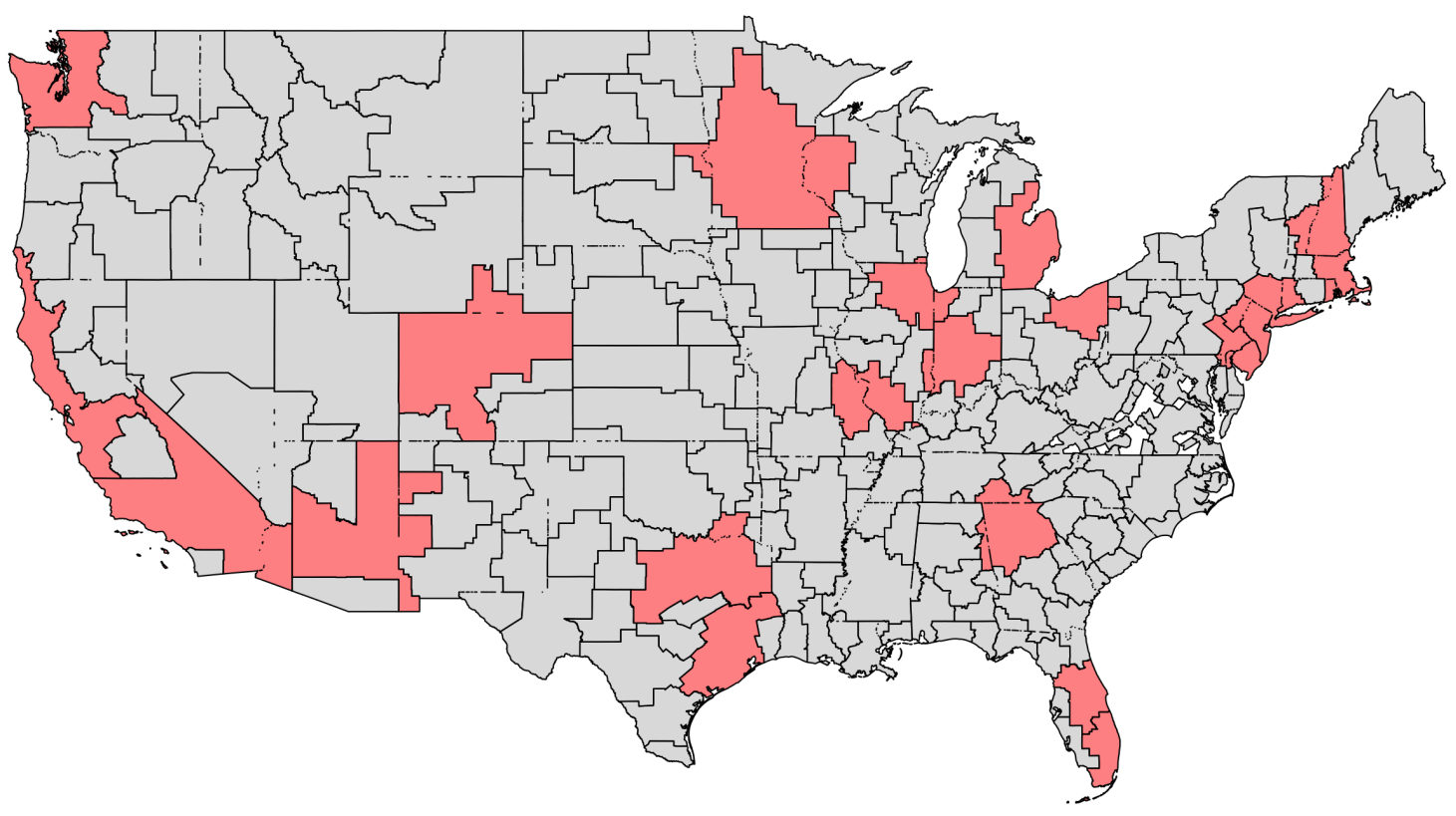


Fig. 2. Firms in New York-Newark-Bridgeport, NY-NJ-CT-PA

This figure plots the firms in our sample, headquartered in the New York-Newark-Bridgeport EA. The light dash lines are the state borders.

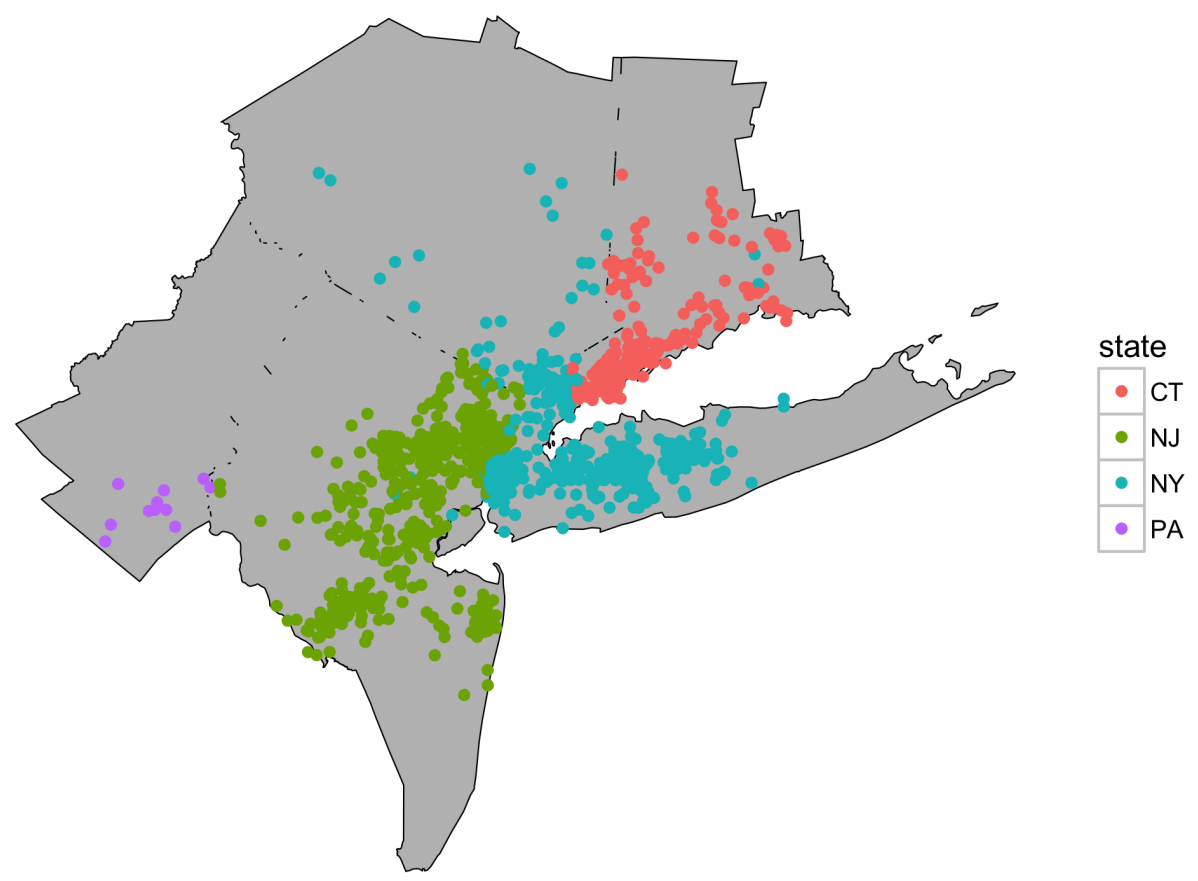




\section{Table 1: Summary Statistics}

The sample consists of all non-financial and non-utility US companies that are traded on the NYSE, AMEX, or NASDAQ during fiscal years 1989 to 2011. The table reports summary statistics for the main variables used in the analyses. Variable definitions are provided in the appendix. The sample in Panel A consists of all firms in the sample. The sample in Panel B consists of firms, headquartered in EAs that span more than one state. Variables are winsorized at $0.5 \%$ in each tail.

\begin{tabular}{lcccccc}
\hline & $\mathrm{N}$ & Mean & Std.Dev & $25^{\text {th }}$ & Median & $75^{\text {th }}$ \\
\hline Panel A: All Firms & & & & & & \\
$I$ & 80,835 & 0.367 & 0.467 & 0.124 & 0.227 & 0.424 \\
$\bar{I}_{-i}$ & 80,178 & 0.368 & 0.129 & 0.280 & 0.356 & 0.440 \\
$q$ & 86,353 & 1.902 & 17.27 & 0.274 & 0.715 & 1.573 \\
Cashflow & 81,059 & 0.134 & 0.256 & 0.0546 & 0.139 & 0.230 \\
ROA & 88,905 & 0.0245 & 0.607 & 0.00884 & 0.104 & 0.167 \\
Leverage & 89,032 & 0.172 & 0.265 & 0.00174 & 0.0998 & 0.273 \\
Asset (in Million \$) & 89,260 & 1,616 & 8,717 & 33.73 & 131.5 & 611.9 \\
\multicolumn{5}{l}{ Panel B: Firms located in EAs that } & span more than & one state \\
I & 37,064 & 0.361 & 0.462 & 0.124 & 0.222 & 0.411 \\
$\bar{I}_{-i}$ & 37,064 & 0.361 & 0.0978 & 0.291 & 0.357 & 0.429 \\
$q$ & 39,734 & 1.790 & 11.24 & 0.261 & 0.714 & 1.585 \\
Cashflow & 37,220 & 0.134 & 0.252 & 0.0564 & 0.141 & 0.228 \\
ROA & 40,636 & 0.0232 & 0.766 & 0.00998 & 0.104 & 0.166 \\
Leverage & 40,721 & 0.173 & 0.308 & 0.00220 & 0.103 & 0.274 \\
Asset (in Million $\$)$ & 40,807 & 1,692 & 7,895 & 31.56 & 128.1 & 614.6 \\
\hline
\end{tabular}




\section{Table 2: Firm Investment and Local Peer Investment}

This table reports the OLS regressions of a firm's investment on the average local firms' investment. The sample consists of all non-financial and non-utility US companies that are traded on the NYSE, AMEX, or NASDAQ during fiscal years 1989 to 2011. The dependent variable is the investment rate for firm $i$ defined as $I_{t}=$ capx $_{t} /$ ppent $_{t-1}$, and the independent variable $\bar{I}_{-i, t}$ is the average investment rate for all firms in an EA, excluding firm $i$. Columns (3) and (4) report regression results from a first-difference estimation. Year, Industry-year, EA and firm fixed effects are included as indicated. Standard errors are clustered at the firm level and reported in parentheses. ${ }^{*}, * *, * * *$ mean significance at ten, five, and one percent, respectively.

\begin{tabular}{|c|c|c|c|c|}
\hline & \multicolumn{2}{|c|}{$I_{t}$} & \multicolumn{2}{|c|}{$\Delta I_{t}$} \\
\hline & $(1)$ & $(2)$ & $(3)$ & $(4)$ \\
\hline $\bar{I}_{-i, t}$ & $\begin{array}{c}0.072^{* * *} \\
(0.020)\end{array}$ & $\begin{array}{c}0.050^{* *} \\
(0.020)\end{array}$ & & \\
\hline$\Delta \bar{I}_{-i, t}$ & & & $\begin{array}{c}0.074^{* * *} \\
(0.022)\end{array}$ & $\begin{array}{c}0.072^{* * *} \\
(0.023)\end{array}$ \\
\hline Cashflow $_{t}$ & $\begin{array}{c}0.270^{* * *} \\
(0.017)\end{array}$ & $\begin{array}{c}0.265^{* * *} \\
(0.017)\end{array}$ & & \\
\hline$q_{t-1}$ & $\begin{array}{c}0.052^{* * *} \\
(0.002)\end{array}$ & $\begin{array}{c}0.051^{* * *} \\
(0.002)\end{array}$ & & \\
\hline$\Delta$ Cashflow $_{t}$ & & & $\begin{array}{c}0.187^{* * *} \\
(0.016)\end{array}$ & $\begin{array}{c}0.188^{* * *} \\
(0.017)\end{array}$ \\
\hline$\Delta q_{t-1}$ & & & $\begin{array}{c}0.041^{* * *} \\
(0.002)\end{array}$ & $\begin{array}{c}0.040^{* * *} \\
(0.002)\end{array}$ \\
\hline Year fixed effect & $\checkmark$ & & & \\
\hline Industry-year fixed effect & & $\checkmark$ & $\checkmark$ & $\checkmark$ \\
\hline Firm fixed effect & $\checkmark$ & $\checkmark$ & & $\checkmark$ \\
\hline Observations & 75,552 & 75,552 & 65,413 & 64,439 \\
\hline R-squared & 0.380 & 0.385 & 0.069 & 0.131 \\
\hline
\end{tabular}




\section{Table 3: Determinants of State Corporate Income Tax Rises}

This table tests determinants of state corporate income tax rises. Column (1) reports the summary statistics of the determinant variables, showing means and standard deviations in parentheses. Columns (2) - (8) report OLS regression results. The dependent variable in these regressions is a dummy variable, taking on the value of 1 if a state increases corporate income tax in year $t$ and 0 otherwise. The explanatory variables Home state $I_{t-1}\left(\Delta I_{t-1}\right)$ is the state aggregate level (growth) of investment in last year, and neighboring state $I_{t-1}\left(\Delta I_{t-1}\right)$ is the aggregate level (growth) of investment of the home state's neighboring states in the last year. Other variables are defined in the appendix and Heider and Ljungqvist (2015). All regressions include state and year fixed effect. Standard errors are clustered at the state level and reported in parentheses. ${ }^{*},{ }^{* *},{ }^{* * *}$ mean significance at ten, five, and one percent, respectively.

\begin{tabular}{|c|c|c|c|c|c|c|c|c|}
\hline & \multirow{2}{*}{$\frac{\text { Sum.Stat. }}{(1)}$} & \multicolumn{7}{|c|}{$=1$ if tax rise } \\
\hline & & $(2)$ & $(3)$ & $(4)$ & $(5)$ & $(6)$ & $(7)$ & $(8)$ \\
\hline Home state $I_{t-1}$ & $\begin{array}{c}0.209 \\
(0.119)\end{array}$ & $\begin{array}{l}-0.050 \\
(0.042)\end{array}$ & & $\begin{array}{l}-0.105 \\
(0.066)\end{array}$ & & & & $\begin{array}{l}-0.085 \\
(0.060)\end{array}$ \\
\hline$\Delta$ Home state $I_{t-1}$ & $\begin{array}{l}-0.006 \\
(0.110)\end{array}$ & & $\begin{array}{c}0.004 \\
(0.019)\end{array}$ & $\begin{array}{l}0.041 \\
(0.026)\end{array}$ & & & & $\begin{array}{c}0.046 \\
(0.031)\end{array}$ \\
\hline Neighboring state $I_{t-1}$ & $\begin{array}{c}0.191 \\
(0.043)\end{array}$ & & & & $\begin{array}{l}-0.177 \\
(0.218)\end{array}$ & & $\begin{array}{l}-0.217 \\
(0.301)\end{array}$ & $\begin{array}{l}-0.102 \\
(0.265)\end{array}$ \\
\hline$\Delta$ Neighboring state $\Delta I_{t-1}$ & $\begin{array}{l}-0.001 \\
(0.032)\end{array}$ & & & & & $\begin{array}{l}-0.198 \\
(0.334)\end{array}$ & $\begin{array}{l}-0.270 \\
(0.266)\end{array}$ & $\begin{array}{l}-0.267 \\
(0.265)\end{array}$ \\
\hline$=1$ if Democratic governor in year $\mathrm{t}-1$ & $\begin{array}{l}0.465 \\
(0.499)\end{array}$ & $\begin{array}{c}0.001 \\
(0.016)\end{array}$ & $\begin{array}{c}0.000 \\
(0.016)\end{array}$ & $\begin{array}{c}0.001 \\
(0.016)\end{array}$ & $\begin{array}{l}-0.002 \\
(0.015)\end{array}$ & $\begin{array}{c}0.002 \\
(0.016)\end{array}$ & $\begin{array}{l}-0.000 \\
(0.015)\end{array}$ & $\begin{array}{c}0.000 \\
(0.015)\end{array}$ \\
\hline$=1$ if 1 year to next gubernatorial election & & $\begin{array}{c}0.038 \\
(0.024)\end{array}$ & $\begin{array}{l}0.038 \\
(0.024)\end{array}$ & $\begin{array}{c}0.038 \\
(0.024)\end{array}$ & $\begin{array}{c}0.031 \\
(0.023)\end{array}$ & $\begin{array}{c}0.034 \\
(0.024)\end{array}$ & $\begin{array}{l}0.030 \\
(0.023)\end{array}$ & $\begin{array}{c}0.033 \\
(0.023)\end{array}$ \\
\hline$=1$ if 2 year to next gubernatorial election & & $\begin{array}{c}0.010 \\
(0.013)\end{array}$ & $\begin{array}{c}0.010 \\
(0.013)\end{array}$ & $\begin{array}{c}0.010 \\
(0.013)\end{array}$ & $\begin{array}{c}0.009 \\
(0.013)\end{array}$ & $\begin{array}{c}0.004 \\
(0.015)\end{array}$ & $\begin{array}{c}0.003 \\
(0.015)\end{array}$ & $\begin{array}{c}0.002 \\
(0.016)\end{array}$ \\
\hline$=1$ if 3 year to next gubernatorial election & & $\begin{array}{c}0.064^{* *} \\
(0.029)\end{array}$ & $\begin{array}{c}0.065^{* *} \\
(0.029)\end{array}$ & $\begin{array}{c}0.064^{* *} \\
(0.029)\end{array}$ & $\begin{array}{c}0.064^{* *} \\
(0.029)\end{array}$ & $\begin{array}{c}0.066^{* *} \\
(0.029)\end{array}$ & $\begin{array}{c}0.060^{* *} \\
(0.028)\end{array}$ & $\begin{array}{l}0.055^{*} \\
(0.029)\end{array}$ \\
\hline State budget balance $t-1$ & $\begin{array}{c}0.019 \\
(0.068)\end{array}$ & $\begin{array}{c}-0.446^{* *} \\
(0.196)\end{array}$ & $\begin{array}{c}-0.458^{* *} \\
(0.196)\end{array}$ & $\begin{array}{c}-0.451^{* *} \\
(0.199)\end{array}$ & $\begin{array}{c}-0.409^{* *} \\
(0.180)\end{array}$ & $\begin{array}{c}-0.388^{* *} \\
(0.175)\end{array}$ & $\begin{array}{c}-0.387^{* *} \\
(0.174)\end{array}$ & $\begin{array}{c}-0.430^{* *} \\
(0.195)\end{array}$ \\
\hline GSP growth rate $_{t-1}$ & $\begin{array}{c}2.728 \\
(2.866)\end{array}$ & $\begin{array}{c}0.002 \\
(0.003)\end{array}$ & $\begin{array}{c}0.002 \\
(0.003)\end{array}$ & $\begin{array}{c}0.002 \\
(0.003)\end{array}$ & $\begin{array}{c}0.002 \\
(0.003)\end{array}$ & $\begin{array}{c}0.002 \\
(0.003)\end{array}$ & $\begin{array}{c}0.001 \\
(0.003)\end{array}$ & $\begin{array}{c}0.001 \\
(0.003)\end{array}$ \\
\hline Unemployment rate $_{t-1}$ & $\begin{array}{c}5.499 \\
(1.829)\end{array}$ & $\begin{array}{c}-0.003 \\
(0.006)\end{array}$ & $\begin{array}{l}-0.002 \\
(0.007)\end{array}$ & $\begin{array}{c}-0.003 \\
(0.006)\end{array}$ & $\begin{array}{l}-0.003 \\
(0.007)\end{array}$ & $\begin{array}{c}-0.002 \\
(0.006)\end{array}$ & $\begin{array}{c}-0.003 \\
(0.007)\end{array}$ & $\begin{array}{c}-0.004 \\
(0.007)\end{array}$ \\
\hline Union penetration $_{t-1}$ & $\begin{array}{c}8.583 \\
(4.409)\end{array}$ & $\begin{array}{c}0.002 \\
(0.006)\end{array}$ & $\begin{array}{c}0.002 \\
(0.007)\end{array}$ & $\begin{array}{c}0.002 \\
(0.007)\end{array}$ & $\begin{array}{c}0.003 \\
(0.007)\end{array}$ & $\begin{array}{c}0.003 \\
(0.007)\end{array}$ & $\begin{array}{c}0.002 \\
(0.006)\end{array}$ & $\begin{array}{c}0.000 \\
(0.006)\end{array}$ \\
\hline Tax competition $_{t-1}$ & $\begin{array}{l}-2.471 \\
(3.130)\end{array}$ & $\begin{array}{c}-0.019^{* * *} \\
(0.006)\end{array}$ & $\begin{array}{c}-0.019^{* * *} \\
(0.006)\end{array}$ & $\begin{array}{c}-0.019^{* * *} \\
(0.006)\end{array}$ & $\begin{array}{c}-0.017^{* * *} \\
(0.006)\end{array}$ & $\begin{array}{c}-0.018^{* * *} \\
(0.006)\end{array}$ & $\begin{array}{c}-0.016^{* *} \\
(0.006)\end{array}$ & $\begin{array}{c}-0.017^{* * *} \\
(0.006)\end{array}$ \\
\hline Year fixed effect & & $\checkmark$ & $\checkmark$ & $\checkmark$ & $\checkmark$ & $\checkmark$ & $\checkmark$ & $\checkmark$ \\
\hline State fixed effect & & $\checkmark$ & $\checkmark$ & $\checkmark$ & $\checkmark$ & $\checkmark$ & $\checkmark$ & $\checkmark$ \\
\hline Observations & & 1,086 & 1,081 & 1,077 & 1,092 & 1,094 & 1,085 & 1,058 \\
\hline R-squared & & 0.123 & 0.123 & 0.125 & 0.125 & 0.121 & 0.123 & 0.122 \\
\hline
\end{tabular}




\section{Table 4: State Corporate Income Tax Rises and Corporate Investment}

This table reports OLS regression results of state corporate income tax rises on the changes of firm investment. The sample consists of all non-financial and non-utility US companies that are traded on the NYSE, AMEX, or NASDAQ during fiscal years 1989 to 2011. The dependent variable is the growth rate of investment for firm $i$, and the independent variable is a dummy taking on the value of one if state increases its corporate income tax and zero otherwise. Firm and local control variables are added in column (3) - (6) and defined in the appendix. All regressions include industry-year fixed effects. EA-year, firm and EA-industry-year fixed effects are included as indicated. Standard errors are clustered at the firm level and reported in parentheses. ${ }^{*},{ }^{*},{ }^{* * *}$ mean significance at ten, five, and one percent, respectively.

\begin{tabular}{|c|c|c|c|c|c|c|}
\hline & $(1)$ & $(2)$ & $(3)$ & (4) & (5) & (6) \\
\hline$=1$ if tax rise & $\begin{array}{l}-0.013^{*} \\
(0.007)\end{array}$ & $\begin{array}{l}-0.025^{*} \\
(0.014)\end{array}$ & $\begin{array}{c}-0.034^{* *} \\
(0.017)\end{array}$ & $\begin{array}{c}-0.044^{* *} \\
(0.019)\end{array}$ & $\begin{array}{c}-0.044^{* *} \\
(0.018)\end{array}$ & $\begin{array}{c}-0.053^{* *} \\
(0.021)\end{array}$ \\
\hline$\Delta$ Cashflow $_{t}$ & & & $\begin{array}{c}0.166^{* * *} \\
(0.016)\end{array}$ & $\begin{array}{c}0.171^{* * *} \\
(0.018)\end{array}$ & $\begin{array}{c}0.171^{* * *} \\
(0.018)\end{array}$ & $\begin{array}{c}0.178^{* * *} \\
(0.019)\end{array}$ \\
\hline$\Delta q_{t-1}$ & & & $\begin{array}{c}0.036^{* * *} \\
(0.002)\end{array}$ & $\begin{array}{c}0.035^{* * *} \\
(0.002)\end{array}$ & $\begin{array}{c}0.035^{* * *} \\
(0.002)\end{array}$ & $\begin{array}{c}0.035^{* * *} \\
(0.002)\end{array}$ \\
\hline$\Delta R O A_{t-1}$ & & & $\begin{array}{c}0.344^{* * *} \\
(0.018)\end{array}$ & $\begin{array}{c}0.355^{* * *} \\
(0.020)\end{array}$ & $\begin{array}{c}0.355^{* * *} \\
(0.020)\end{array}$ & $\begin{array}{c}0.355^{* * *} \\
(0.021)\end{array}$ \\
\hline$\Delta$ Leverage $_{t-1}$ & & & $\begin{array}{c}-0.306^{* * *} \\
(0.020)\end{array}$ & $\begin{array}{c}-0.278^{* * *} \\
(0.020)\end{array}$ & $\begin{array}{c}-0.278^{* * *} \\
(0.020)\end{array}$ & $\begin{array}{c}-0.279^{* * *} \\
(0.023)\end{array}$ \\
\hline$\Delta \log (\text { Asset })_{t-1}$ & & & $\begin{array}{c}-0.157^{* * *} \\
(0.008)\end{array}$ & $\begin{array}{c}-0.175^{* * *} \\
(0.009)\end{array}$ & $\begin{array}{c}-0.175^{* * *} \\
(0.009)\end{array}$ & $\begin{array}{c}-0.176^{* * *} \\
(0.010)\end{array}$ \\
\hline GSP growth rate $_{t-1}$ & & & $\begin{array}{l}-0.002 \\
(0.002)\end{array}$ & $\begin{array}{l}-0.003 \\
(0.002)\end{array}$ & $\begin{array}{l}-0.003 \\
(0.002)\end{array}$ & $\begin{array}{l}-0.004 \\
(0.003)\end{array}$ \\
\hline Unemployment rate $_{t-1}$ & & & $\begin{array}{l}-0.003 \\
(0.005)\end{array}$ & $\begin{array}{l}-0.000 \\
(0.006)\end{array}$ & $\begin{array}{l}-0.000 \\
(0.006)\end{array}$ & $\begin{array}{l}-0.002 \\
(0.007)\end{array}$ \\
\hline Union penetration $_{t-1}$ & & & $\begin{array}{c}0.001 \\
(0.001)\end{array}$ & $\begin{array}{c}0.006 \\
(0.005)\end{array}$ & $\begin{array}{c}0.006 \\
(0.005)\end{array}$ & $\begin{array}{c}0.005 \\
(0.005)\end{array}$ \\
\hline Tax competition $_{t-1}$ & & & $\begin{array}{l}-0.002 \\
(0.001)\end{array}$ & $\begin{array}{c}-0.006^{* *} \\
(0.003)\end{array}$ & $\begin{array}{c}-0.006^{* *} \\
(0.003)\end{array}$ & $\begin{array}{c}-0.008^{* * *} \\
(0.003)\end{array}$ \\
\hline Population growth ${ }_{t-1}$ & & & $\begin{array}{l}0.252 \\
(0.323)\end{array}$ & $\begin{array}{c}0.159 \\
(0.350)\end{array}$ & $\begin{array}{c}0.157 \\
(0.349)\end{array}$ & $\begin{array}{c}0.083 \\
(0.383)\end{array}$ \\
\hline Employment growth $_{t-1}$ & & & $\begin{array}{l}-0.557 \\
(0.450)\end{array}$ & $\begin{array}{l}-0.598 \\
(0.549)\end{array}$ & $\begin{array}{l}-0.612 \\
(0.556)\end{array}$ & $\begin{array}{l}-0.665 \\
(0.663)\end{array}$ \\
\hline$=1$ if tax rise in $t-1$ & & & & & $\begin{array}{c}0.006 \\
(0.016)\end{array}$ & $\begin{array}{c}0.015 \\
(0.018)\end{array}$ \\
\hline$=1$ if tax rise in $t+1$ & & & & & $\begin{array}{l}-0.005 \\
(0.017)\end{array}$ & $\begin{array}{l}-0.001 \\
(0.019)\end{array}$ \\
\hline Industry-year fixed effect & $\checkmark$ & $\checkmark$ & $\checkmark$ & $\checkmark$ & $\checkmark$ & $\checkmark$ \\
\hline EA-year fixed effect & & $\checkmark$ & $\checkmark$ & $\checkmark$ & $\checkmark$ & $\checkmark$ \\
\hline Firm fixed effect & & & & $\checkmark$ & $\checkmark$ & $\checkmark$ \\
\hline EA-industry-year fixed effect & & & & & & $\checkmark$ \\
\hline Observations & 72,869 & 72,226 & 64,555 & 63,546 & 63,546 & 59,148 \\
\hline R-squared & 0.026 & 0.051 & 0.117 & 0.181 & 0.181 & 0.237 \\
\hline
\end{tabular}




\section{Table 5: The Causal Effect of Local Peer Firm Investment}

This table reports first (Panel B) and second stage (Panel A) regression results from a 2SLS regression using first-differences. The sample consists of non-financial and non-utility US companies that are traded on the NYSE, AMEX, or NASDAQ during fiscal years 1989 to 2011, located in an EA that spans more than one state. The dependent variable is the growth rate of investment for firm $i$. The endogenous variable is the average investment rate for all firms in an EA and year, excluding firm $i$. The excluded instrument in column (1) is a dummy variable, taking on the value of one if a neighboring state of firm $i$ increases its corporate tax, or zero otherwise. The excluded instruments in column $(2) /(3)$ are the predicted changes in the state-specific/state-industry-specific leave-out mean of the investment rate based on a firm-level regression of the change in investment rate on a tax rise dummy. All regressions include firm and local control variables, industry-year and firm fixed effects. Standard errors are clustered at the firm level and reported in parentheses. ${ }^{*},{ }^{* *},{ }^{* * *}$ mean significance at ten, five, and one percent, respectively.

\section{Panel A: Second stage}

$(1)$

$-3.159^{* *}$

28,616

35.48
$(2)$

$-2.077^{* *}$

28,616

47.94
(3)

$-2.433^{* *}$

28,616

48.38

\section{Panel B: First stage}

$=1$ if tax rise in neighboring state

Predicted state-specific $\Delta \bar{I}_{-i, t}$

Predicted state-industry-specific $\Delta \bar{I}_{-i, t}$

Firm and local controls

Industry-year fixed effect

Firm fixed effect
$-0.008^{* * *}$

(0.001)

$\begin{array}{ccc} & 0.483^{* * *} \\ & (0.070) & \\ & & 0.424^{* * *} \\ & & (0.061) \\ & & \\ \checkmark & \checkmark & \checkmark \\ \checkmark & \checkmark & \checkmark \\ \checkmark & \checkmark & \checkmark \\ 28,616 & 28,616 & 28,616 \\ & & \end{array}$




\section{Table 6: Robustness Check: Local Peer Firm Effects at MSAs}

This table reports the 2SLS results (Table 5) using a different geographical definition as robustness checks. The sample contains firms located in a MSA that spans more than one state and restricts attention to non-financial and non-utility US companies that are traded on the NYSE, AMEX, or NASDAQ during fiscal years 1989 to 2011. The dependent variable is the growth rate of investment for firm $i$. The endogenous variable is the average investment rate for all firms in a MSA and year, excluding firm $i$. The excluded instrument in column (1) is a dummy variable, taking on the value of one if a neighboring state of firm $i$ increases its corporate tax and zero otherwise. The excluded instruments in column $(2) /(3)$ are the predicted change in the state-specific/state-industry-specific leave-out mean of the investment rate based on a firm-level regression of the change in investment rate on a tax rise dummy. All regressions include firm and local control variables, industry-year and firm fixed effects. Standard error are clustered at the firm level and reported in parentheses. ${ }^{*},{ }^{*},{ }^{* * *}$ mean significance at ten, five, and one percent, respectively.

Panel A: Second stage

(1) (2) (3)

\begin{tabular}{lccc}
$\Delta \bar{I}_{-i, t}$ & $-2.588^{* *}$ & $-2.720^{* *}$ & $-2.549^{* *}$ \\
& $(1.155)$ & $(1.225)$ & $(1.160)$ \\
Observations & & & \\
$\mathrm{F}$ & 18,384 & 18,384 & 18,384 \\
\hline
\end{tabular}

Panel B: First stage

$=1$ if tax rise in neighboring state $-0.016^{* * *}$

Predicted state-specific $\Delta \bar{I}_{-i, t}$

Predicted state-industry-specific $\Delta \bar{I}_{-i, t}$ $0.723^{* * *}$

$0.683^{* * *}$

Firm and local controls Industry-year fixed effect Firm fixed effect

$\begin{array}{lll}\checkmark & \checkmark & \checkmark \\ \checkmark & \checkmark & \checkmark \\ \checkmark & \checkmark & \checkmark\end{array}$

Observations

18,384
18,384

18,384 


\section{Table 7: Border States' Tax Rises on Investment (Reduced Form Analysis)}

This table reports OLS regression results of a tax rise in a neighboring state on firm investment. The sample consists of non-financial and nonutility US companies that are traded on the NYSE, AMEX, or NASDAQ during fiscal years 1989 to 2011. The dependent variable is the growth rate of investment for firm $i$. The variable " $=1$ if tax rise" is a dummy variable taking on the value of one if the home state of firm $i$ rises its corporate income tax in year $t$ and zero otherwise; " $=1$ if tax rise in neighboring state(s)" is a dummy variable taking on the value of 1 if a firm $i$ 's neighboring state raises its corporate income tax in year $t$ and zero otherwise; " $=1$ if tax rise in neighboring state and firm HQ in bordering county" is a dummy taking on the value of 1 if a firm $i$ is headquartered in bordering county in which state raises its corporate income tax in year $t ;$ " $=1$ if tax rise in neighboring state and firm HQ in non-bordering county" is a dummy taking on the value of 1 if a firm $i$ is headquartered in hinterland counties in neighboring state that raises its corporate income tax in year $t$. All regressions include industry-year fixed effects. Firm and local control variables, EA, firm, EA-year and EA-industry-year fixed effects are included as indicated. Standard errors are clustered at the firm level and reported in parentheses. $*, * *, * *$ mean significance at ten, five, and one percent, respectively.

$(1)$

\section{$0.009^{*}$}

$=1$ if tax rise in neighboring state(s)

$=1$ if tax rise in neighboring state and

$(0.005)$

$(2)$

(3)

(4)

(5)

$(6)$

$=1$ if tax rise in neighboring state and firm HQ in non-bordering county
$-0.021^{* * *}$

(0.008)

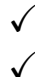

Industry - year FE

EA FE

Firm FE

EA-year FE

EA-industry-year FE

$\begin{array}{ccccc}0.020^{* * *} & 0.016^{*} & 0.020^{* *} & 0.035^{*} & 0.038^{*} \\ (0.007) & (0.008) & (0.009) & (0.018) & (0.021) \\ 0.005 & 0.001 & 0.004 & 0.020 & 0.021 \\ (0.005) & (0.006) & (0.006) & (0.017) & (0.019) \\ & & & & \\ -0.025^{* * *} & -0.018^{*} & -0.017 & -0.058^{* * *} & -0.069^{* * *} \\ (0.008) & (0.010) & (0.011) & (0.021) & (0.024)\end{array}$

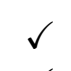

$\checkmark$

$$
\begin{aligned}
& \checkmark \\
& \checkmark \\
& \checkmark \\
& \checkmark
\end{aligned}
$$

\begin{tabular}{|c|c|c|c|c|c|c|}
\hline Observations & 72,866 & 72,866 & 65,178 & 64,178 & 63,546 & 59,148 \\
\hline R-squared & 0.027 & 0.027 & 0.096 & 0.160 & 0.182 & 0.238 \\
\hline
\end{tabular}




\section{Table 8: Local Peer Effect and Competition}

This table reports second stage regression results from a 2SLS regression using first-differences. The sample consists of non-financial and non-utility US companies that are traded on the NYSE, AMEX, or NASDAQ during fiscal years 1989 to 2011, located in an EA that spans more than one state. The dependent variable is the growth rate of investment for firm $i$. The endogenous variable is the average investment rate for all firms in an EA and year, excluding firm $i$. The endogenous variable is interacted with a dummy variable, taking on the value of one if the asset share of firms in the same FF12-industry (TNIC3) within an EA is above the median share within an EA ("=1 if more peers in EA") in column (1)-(3) $((4)-(6))$. The endogenous variable as well as the interaction of the endogenous variable with the aforementioned dummies are instrumented. The excluded instrument in columns (1) is a dummy variable, taking on the value of one if a neighboring state of firm $i$ increases its corporate tax and zero otherwise. The excluded instruments in columns (2)/(3) are the predicted change in the state-specific/state-industry-specific leave-out mean of the investment rate based on a firm-level regression of the change in investment rate on a tax rise dummy. All regressions include firm and local control variables, industry-year and firm fixed effects. Standard errors are clustered at the firm level and reported in parentheses. ${ }^{*}, * *, * * *$ mean significance at ten, five, and one percent, respectively.

\begin{tabular}{|c|c|c|c|c|c|c|}
\hline & $(1)$ & $(2)$ & $(3)$ & $(4)$ & $(5)$ & $(6)$ \\
\hline & \multicolumn{3}{|c|}{ Fama-French 12} & \multicolumn{3}{|c|}{ TNIC3 } \\
\hline$\Delta \bar{I}_{1,-i, t}$ & $\begin{array}{c}-2.581^{* *} \\
(1.240)\end{array}$ & $\begin{array}{c}-1.483^{*} \\
(0.893)\end{array}$ & $\begin{array}{c}-1.808^{*} \\
(0.971)\end{array}$ & $\begin{array}{c}-3.379^{* *} \\
(1.622)\end{array}$ & $\begin{array}{c}-2.048^{* *} \\
(1.026)\end{array}$ & $\begin{array}{c}-2.474^{* *} \\
(1.143)\end{array}$ \\
\hline$\Delta \bar{I}_{1,-i, t} *(=1$ if more peers in EA $)$ & $\begin{array}{c}-0.860^{*} \\
(0.465)\end{array}$ & $\begin{array}{c}-0.801^{* * *} \\
(0.297)\end{array}$ & $\begin{array}{c}-0.877^{* * *} \\
(0.320)\end{array}$ & $\begin{array}{c}-0.753^{*} \\
(0.425)\end{array}$ & $\begin{array}{c}-0.735^{* * *} \\
(0.278)\end{array}$ & $\begin{array}{c}-0.792^{* * *} \\
(0.294)\end{array}$ \\
\hline $\begin{array}{l}\text { Excluded instrument: } \\
=1 \text { if tax rise in neighboring state } \\
\text { Predicted state-specific } \Delta \bar{I}_{-i, t} \\
\text { Predicted state-industry-specific } \Delta \bar{I}_{-i, t}\end{array}$ & $\checkmark$ & $\checkmark$ & $\checkmark$ & $\checkmark$ & $\checkmark$ & $\checkmark$ \\
\hline $\begin{array}{l}\text { Firm and local controls } \\
\text { Industry-year FE } \\
\text { Firm FE }\end{array}$ & $\begin{array}{l}\checkmark \\
\checkmark \\
\checkmark\end{array}$ & $\begin{array}{l}\checkmark \\
\checkmark \\
\checkmark\end{array}$ & $\begin{array}{l}\checkmark \\
\checkmark \\
\checkmark\end{array}$ & $\begin{array}{l}\checkmark \\
\checkmark \\
\checkmark\end{array}$ & $\begin{array}{l}\checkmark \\
\checkmark \\
\checkmark\end{array}$ & $\begin{array}{l}\checkmark \\
\checkmark \\
\checkmark\end{array}$ \\
\hline $\begin{array}{l}\text { Observations } \\
\text { F }\end{array}$ & $\begin{array}{c}28,616 \\
17.73\end{array}$ & $\begin{array}{c}28,616 \\
24.18\end{array}$ & $\begin{array}{c}28,616 \\
24.24\end{array}$ & $\begin{array}{c}27,312 \\
12.74\end{array}$ & $\begin{array}{l}27,312 \\
22.26\end{array}$ & $\begin{array}{c}27,312 \\
21.47\end{array}$ \\
\hline
\end{tabular}




\section{Appendix A. Variable Definition}

\section{$\underline{\text { Firm-level characteristics }}$}

$\boldsymbol{I}$ is constructed by scaling a firm's capital expenditure (capx) by its net gross book value of fixed assets (ppent) in the previous year.

$\boldsymbol{I}_{-\boldsymbol{i}}$ is the average investment of a firm $i$ 's local peers at the EA-year level, excluding firm $i$.

$\boldsymbol{q}$ is the Tobin's Q, calculated as $(\mathrm{dltt}+\mathrm{dlc}+$ csho * prcc $f-$ act $) /($ ppegt + intangible capital $)$, where intangible capital is estimated by Peters and Taylor (2017).

Cashflow is calculated $(\mathrm{ib}+\mathrm{dp}+(\mathrm{xrd}+0.3 *$ sga $) *(1-0.3)) /$ l. (ppegt + intangible capital $)$, where intangible capital is estimated by Peters and Taylor (2017).

$\log ($ Asset $)$ is defined as the natural logarithm of firm book value of assets (at).

Leverage is defined as long-term debt (dltt) over the book value of assets (at).

$\boldsymbol{R O} \boldsymbol{A}$ is defined as operating income before depreciation (oibdp) over the book value of assets (at).

\section{$\underline{\text { State-level characteristics }}$}

GSP growth rate is the annual growth rate of gross state product (GSP), obtained from the U.S.

Bureau of Economic Analysis.

Unemployment rate is the state unemployment rate, obtained from the U.S. Bureau of Labor Statistics.

Population growth rate is the annual growth rate of population in an EA, aggregated based on county-level statistics from Census.

Employment growth rate is the annual growth rate of employment rate, aggregated based on county-level statistics from Census.

State union penetration is the fraction of private-sector employees in a state who belong to a labor union in year t. The data come from Hirsch and Macpherson (2003) as updated on their 
website, http://www.unionstats.com.

State budget balance equals the difference between a states general revenues and its general expenditures scaled by its general expenditures, from the U.S. Census Bureaus State \& Local Finances database.

Tax competition is defined as the difference between a states corporate income tax rate and the highest corporate income tax rate levied by any of the neighboring states.

Home State $\boldsymbol{I}$ is the state aggregate investment, calculated as the summation of capital expenditure (capx) in home state over the summation of net gross book value of fixed assets (ppent) in home state in the previous year.

Neighboring State $\boldsymbol{I}$ is the neighboring states aggregate investment, calculated as the summation of capital expenditure (capx) in neighboring state(s) over the summation of net gross book value of fixed assets (ppent) in neighboring state(s) in the previous year. 


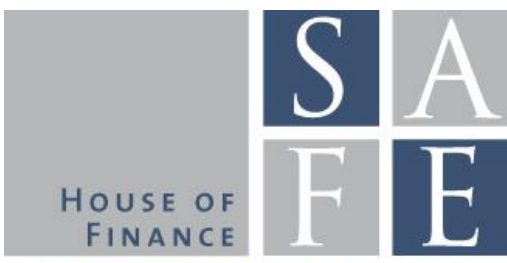

WORKING PAPER SERIES

\section{Recent Issues}

No. 219 Andreas Hackethal - Christine Laudenbach - Steffen Meyer Annika Weber

No. 218 Florian Hoffmann, Roman Inderst, Marcus Opp

No. 217 Maddalena Davoli, Jia Hou

No. 216 Stefano Colonnello, Giuliano Curatola, Alessandro Gioffré

No. 215 Zsuzsa R. Huszár, Zorka Simon

No. 214 Edin Ibrocevic, Matthias Thiemann

No. 213 Klaus Gugler, Michael Weichselbaumer, Christine Zulehner

No. 212 Henning Hesse

No. 211 Thomas Mosk

No. 210 Darien Huang, Christian Schlag, Ivan Shaliastovich, Julian Thimme

No. 209 Eren Gürer, Alfons J. Weichenrieder

No. 208 Roberto Casarin, Michele Costola, Erdem Yenerdag

No. 207 Claes Bäckman, Tobin Hanspal
Client Involvement in Expert Advice Antibiotics in Finance?

Only Time will Tell: A Theory of Deferred Compensation

Financial Literacy and Socialist Education: Lessons from the German Reunification

Pricing Sin Stocks: Ethical Preference vs. Risk Aversion

The Pricing Implications of the Oligopolistic Securities Lending Market:

A Beneficial Owner Perspective

All Economic Ideas are Equal, but Some are more Equal than Others: A Differentiated Perspective on Macroprudential Ideas and their Implementation

Effects of Government Spending on Employment: Evidence from Winners and Runners-up in Procurement Auctions

Incentive Effects from Write-down CoCo Bonds: An Empirical Analysis

Bargaining with a Bank

Volatility-of-Volatility Risk

Pro-rich Inflation in Europe: Implications for the Measurement of Inequality

Financial Bridges and Network Communities

The Geography of Alternative Work 